\title{
Selective response mechanism of a platinum disk electrode modified with polyacrylamide membrane conjugated with gallium (III) phthalocyaninate
}

\author{
Jujie Ren, Hirofumi Watanabe, Shusaku Yamamura, and Toshio Nakamura* \\ Faculty of Science, Shinshu University, Asahi, Matsumoto 390-8621, Japan
}

\begin{abstract}
A non-plasticized polyacrylamide polymer (PAA) coupled to (phthalocyaninato) gallium(III) ([Ga(pc) $\left.]^{\dagger}\right)$, PAA-([Ga(pc)], was synthesized firstly. The potentiometric response behavior of PAA-[Ga(pc)] modified platinum electrode was examined for some ions in such nonaqueous solvents as acetonitrile (AN), dimethylacetamide (DMA), and N-methylpyrrolidinone (NMP). The electrode showed a Nernstian or a near-Nernstian response to $\mathrm{CN}^{-}$and $\mathrm{F}^{-}$in $\mathrm{AN}, \mathrm{DMA}$, and NMP, but it showed a non-thermodynamic response to $\mathrm{Cl}^{-}$and $\mathrm{Br}^{-}$in all the above solvents. Besides spectrophotometric method, cyclic voltammetric investigation was performed to explain the reaction of $[\mathrm{Ga}(\mathrm{pc})]^{+}$with the ions in above solvents. The results revealed that such specially selective response phenomena were due to the complex formation reactions of the ions with $[\mathrm{Ga}(\mathrm{pc})]^{+}$. The reactions were interpreted by the shift of the maximum absorption peak, the appearance of the new peaks on UV-vis spectra of $[\mathrm{Ga}(\mathrm{pc})]^{+}$with the existence of $\mathrm{CN}^{-}$and $\mathrm{F}^{-}$and the clear difference of the redox voltammogram of $[\mathrm{Ga}(\mathrm{pc})]^{+}$at platinum electrode between the adding of $\mathrm{F}^{-}$and $\mathrm{Br}^{-}$in DMA. The three solvents did not show obvious different influence on the complexing. The electrode could be applicable to obtain the solubility product of $\mathrm{NaF}$ in $\mathrm{AN}$.
\end{abstract}

Keywords: nonaqueous solution; phthalocyanine complex; hydrophilic polymer membrane; fluoride; cyanide; potential response mechanism 


\section{Introduction}

Potentiometric methods based on ion-selective electrodes have great advantages such as speed, ease of preparation, reasonable selectivity, low cost, and wide application. Potentiometric measurements can also reveals precise information of the chemical interactions occurred at polymer membrane-solution interface for polymer-modified electrode. In order to develop a highly specific ion-selective electrode, the interaction between the analyte ion and the membrane on electrode surface is a significant subject and it is a classical but essential problem to understand the selective response mechanism of ion-selective electrodes.

Metal phthalocyanines $([\mathrm{M}(\mathrm{pc})])$ and porphyrins have been used as a host compound of sensors for various anions, e.g., a porphyrin-gallium complex has been used to prepare an anion sensor for $\mathrm{F}^{-}$, although those are almost for use in aqueous solution systems [1-3]. Some investigations concerning the characteristics of metallophthalocyanines in dipolar aprotic solvents have also been carried out by UV-vis spectrophotometric measurement [4-7]. Some anion sensing materials that were consisted of non-plasticized polyacrylamide polymer (PAA) coupled to phthalocyaninato complex ([Co(pc)], [VO(pc)] and [ $\mathrm{Sn}(\mathrm{pc})])$ have been developed for use in dipolar aprotic solutions[8-10]. All of these electrodes showed selective Nernstian response to $\mathrm{CN}^{-}$and $\mathrm{F}^{-}$in some aprotic solvent although the center metal of the host compound were different.

The aim of our study was to gain a better understanding of the response mechanism of this kind of electrode, the influences of the center metal of the host compound on the response of the electrode and the applicability of the electrode in different solvents, in the present work a new sensing material, non-plasticized PAA coupled to (phthalocyaninato) gallium(III) $\left([\mathrm{Ga}(\mathrm{pc})]^{+}\right)$was synthesized firstly. Next, the potentiometric response measurement of a platinum electrode modified with the membrane of this material (PAA-[Ga(pc)]) for such anions as $\mathrm{CN}^{-}, \mathrm{F}^{-}, \mathrm{Cl}^{-}$, and $\mathrm{Br}^{-}$in the aprotic solvents of AN, DMA and NMP were carried out. Thirdly, UV-vis spectrophotometric and cyclic voltammetric investigations about the interaction of $[\mathrm{Ga}(\mathrm{pc})]^{+}$with the 
ions in AN, DMA, and NMP were performed to explain the selective response of the electrode. Fourthly, The selectivity coefficient of the electrode for $\mathrm{F}^{-}$over $\mathrm{CN}^{-}$in $\mathrm{AN}$ were also measured to explain the extent of the interaction of $[\mathrm{Ga}(\mathrm{pc})]^{+}$with $\mathrm{F}^{-}$and $\mathrm{CN}^{-}$. Finally, the PAA- $[\mathrm{Ga}(\mathrm{pc})]$ electrode was used to obtain the solubility product constant of $\mathrm{NaF}$ in $\mathrm{AN}$.

\section{Experimental}

\subsection{Reagents}

[Ga(pc)]Cl was purchased from Aldrich (No. 40880-8) and conjugated to carboxy-modified PAA by the same method as that reported in a previous paper [8]. Tetraethylammonium perchlorate $\left(\mathrm{Et}_{4} \mathrm{NClO}_{4}\right)$ was a polarographic grade product purchased from Nacalai Tesque (No. 330-16). It was dried at $65{ }^{\circ} \mathrm{C}$ for 3 hours under a high vacuum with $\mathrm{P}_{2} \mathrm{O}_{5}$. Tetrabutylammonium fluoride $\left(\mathrm{Bu}_{4} \mathrm{NF}\right)$, bromide $\left(\mathrm{Bu}_{4} \mathrm{NBr}\right)$ and Tetraethylammonium chloride $\left(\mathrm{Et}_{4} \mathrm{NCl}\right)$, cyanide $\left(\mathrm{Et}_{4} \mathrm{NCN}\right)$ were purchased from Fluka Co., Ltd., and were used without further purification.

2.2 Solvents

DMA was a reagent grade of Wako (No. 045-02916) and distilled two times by fractional distillation apparatus (packed column is the type of Shibata Scientific Technology Ltd) after treating with molecular sieves (4A 1/16). The first distillation was carried out in the presence of $\mathrm{BaO}$, and second in the presence of $\mathrm{CaH}_{2}$ under a reduced pressure (ca. $15 \mathrm{mmHg}$ ) and nitrogen gas. NMP was also a reagent grade of Wako (No. 136-07616) and fractionally distilled twice after treating with molecular sieves (4A 1/16) under reduced pressure (ca. 10 
$\mathrm{mmHg}$ ) and nitrogen gas.

2.3 Indicator electrode and potentiometric measurement.

The host compound, $[\mathrm{Ga}(\mathrm{pc})]^{+}$, was converted to the amines via the respective nitro derivative. The modified host compound was then conjugated at the carboxyl group of carboxyl-modified polyacrylamide by reaction in DMF following the procedure of Bauminger and Wilchek to obtain the final polymer conjugate, PAA-[Ga(pc)]. A small amount of the conjugate polymer was dissolved in $20 \mu 1$ water and spread on the end surface of a platinum rod with the diameter of $2 \mathrm{~mm}$ housed in the Teflon body. After the electrode stored in silica gel desiccators for about more than four hours, a thin (less than $0.02 \mathrm{~mm}$ ) membrane was formed on the end of the electrode. Then, the electrode was conditioned for more than seven hours in the solution containing $10 \mathrm{mM}$ indifferent electrolyte shown in Cell 1 . The potentiometric response behavior of the PAA-[Ga(pc)] electrode to various anions was investigated by measuring Cell 1; the emfs were measured with a $\mathrm{pH}$ meter $(\Phi 71$, Beckman)and recorded by a recorder (LR4110E, Yokokawa Denki Co.). All compartments of Cell 1 were prepared freshly every time. Steady state potentials were read to $0.1 \mathrm{mV}$.

$$
\begin{aligned}
& \mathrm{Ag} \mid 10 \mathrm{mM} \mathrm{AgNO}_{3}+10 \mathrm{mM} \mathrm{Et}_{4} \mathrm{NClO}_{4}(\mathrm{AN})|| 50 \mathrm{mM} \mathrm{Et}_{4} \mathrm{~N} \mathrm{ClO}_{4}(\mathrm{AN}) \| \\
& c \mathrm{R}_{4} \mathrm{NY}+10 \mathrm{mM} \mathrm{Et}_{4} \mathrm{NClO}_{4} \text { (D) }|\mathrm{PAA}-[\mathrm{Ga}(\mathrm{pc})]| \mathrm{Pt} \quad \ldots . . \text { Cell 1, }
\end{aligned}
$$

Where, $\mathrm{D}=\mathrm{AN}$, DMA, and NMP; $\mathrm{Y}^{-}=\mathrm{CN}^{-}, \mathrm{F}^{-}, \mathrm{Cl}^{-}$, and $\mathrm{Br}^{-} ; \mathrm{R}_{4} \mathrm{~N}^{+}=$tetraethylammonium ion $\left(\mathrm{Et}_{4} \mathrm{~N}^{+}\right)$and tetrabutylammonium ion $\left(\mathrm{Bu}_{4} \mathrm{~N}^{+}\right)$, and $c$ means concentration $\left(\mathrm{mol} \mathrm{dm}{ }^{-3}\right)$. $\mathrm{R}_{4} \mathrm{NY}$ was added by microburet that was a type of Gilmont S-1200. The change of liquid-junction potentials of Cell 1 during emf measurements can be negligible in the experiment [11]

\subsection{UV-vis spectra measurements}


UV-vis spectra Measurements were carried out by the same method reported previously [8]. At first, $[\mathrm{Ga}(\mathrm{pc})]^{+}$saturated AN, DMA or NMP solutions $(<0.01 \mathrm{mM})$ were prepared and for DMA and NMP, the solutions were diluted by a factor of five. Then, solutions with various concentrations of each anion in the above solution were made.

2.5 Cyclic voltammetric measurements

Cyclic voltammetric experiments were performed at room temperature using an arbitrary function generator (HB105 Hokuto Denko) and a potentiostat/galvanostat (HA150). The electrochemical cell was assembled with a three-electrode system: a Pt disk (diameter $2 \mathrm{~mm})$ working electrode, a $\mathrm{Ag}^{+} / \mathrm{Ag}\left(\mathrm{Ag} \mid 10 \mathrm{mM} \mathrm{AgNO}_{3}, 10 \mathrm{mM}\right.$ $\mathrm{Et}_{4} \mathrm{NClO}_{4}$ in $\mathrm{AN}$ ) reference electrode, and a Pt counter electrode. The scan rate was $100 \mathrm{mV} / \mathrm{s}$ over the relevant potential range.

\section{Results and discussion}

3.1 Potentiometric results

The potentiometric response behaviors of the PAA-[Ga(pc)] electrode to such anions as $\mathrm{CN}^{-}, \mathrm{F}^{-}, \mathrm{Cl}^{-}$, and $\mathrm{Br}^{-}$in AN, DMA, and NMP was studied. A typical dynamic response curves for the addition of $\mathrm{F}^{-}$in $\mathrm{AN}$ at PAA- $[\mathrm{Ga}(\mathrm{pc})]$ electrode is shown in Fig.1 and the response results are summarized in Table 1. 


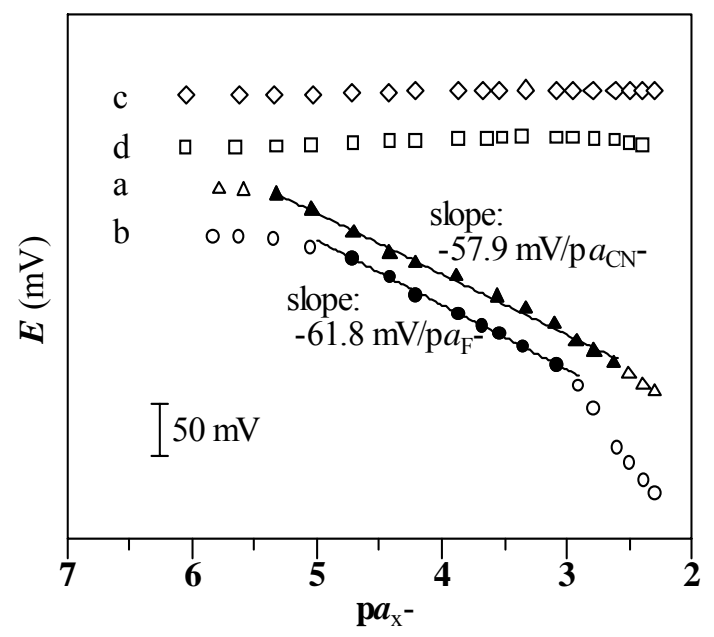

Fig. 1. Potentiometric calibration curves for the ions in acetonitrile at PAA-[Ga(pc) $]$ electrode.

Table1 The response for various anions at the PAA- $[\mathrm{Ga}(\mathrm{pc})]$ electrode in acetonitrile, N,N-dimethylacetamide, and N-methl-2-pyrrolidinane

Slopes are in $\mathrm{mV} / \operatorname{loga}_{\mathrm{x}^{-}}$and figures in ( ) are the linear range in $\mathrm{pa}_{\mathrm{x}}$ - at $25^{\circ} \mathrm{C}$.

\begin{tabular}{cccc}
\hline Ion & AN $\left(14.1^{\mathrm{a}}\right)$ & DMA $\left(27.8^{\mathrm{a}}\right)$ & NMP $\left(27.3^{\mathrm{a}}\right)$ \\
\hline $\mathrm{F}^{-}$ & -58.6 & -57 & -59.7 \\
& $(3.0-5.0)$ & $(3.0-5.9)$ & $(3.3-4.7)$ \\
$\mathrm{CN}^{-}$ & -58.8 & -55.1 & -55.2 \\
& $(2.5-5.4)$ & $(2.5-5.6)$ & $(2.3-4.7)$ \\
$\mathrm{Cl}^{-}$ & +4.2 & +3.8 & +23.2 \\
& $(3.0-5.3)$ & $(2.9-6.0)$ & $(2.4-5.5)$ \\
$\mathrm{Br}^{-}$ & +2.2 & & \\
& $(3.0-5.4)$ & $(4.5-5.9)$ & +8.8 \\
\hline
\end{tabular}

a: the donor number of the solvent

The slopes in the table have deviations of $\pm 0.3 \mathrm{mV} / \mathrm{p} a_{\mathrm{X}^{-}}$for those ions showing a Nernstian or near-Nernstian response, and $\pm 4 \mathrm{mV} / \mathrm{p} a_{\mathrm{X}}$ - for those showing a non-Nernstian response in the repeated four or five times experiments, respectively. The linear ranges of the slopes in the Nernstian equation are also shown under each slope. The lowest activities of these range was the lower detection limit of the electrode. The response can classified into two groups. The first group (Group A: $\mathrm{CN}^{-}$and $\mathrm{F}^{-}$) showed a Nernstian or near-Nernstian 
response in AN, DMA, and NMP. The second (Group B: $\mathrm{Cl}^{-}$and $\mathrm{Br}^{-}$) showed a non-Nernstian response in all solvents investigated, in that the slopes are positive in spite of anions. The time taken to reach steady tstate potential was less than 5 minutes for the ions in Group A but longer for those in Group B.

3.2 Spectrophotometric results.

\subsubsection{Spectra in AN}

In order to understand the peculiar selective response mechanism of the PAA-[Ga(pc)] electrode to the anions in aprotic solvents, spectrophotometric investigations were carried out. The AN solution of $\mathrm{Bu}_{4} \mathrm{NF} \cdot 3 \mathrm{H}_{2} \mathrm{O}$ or $\mathrm{Et}_{4} \mathrm{NCN}$ were added stepwise to $[\mathrm{Ga}(\mathrm{pc})] \mathrm{Cl}$ saturated AN solutions. Typical spectra are shown in Fig. 2.

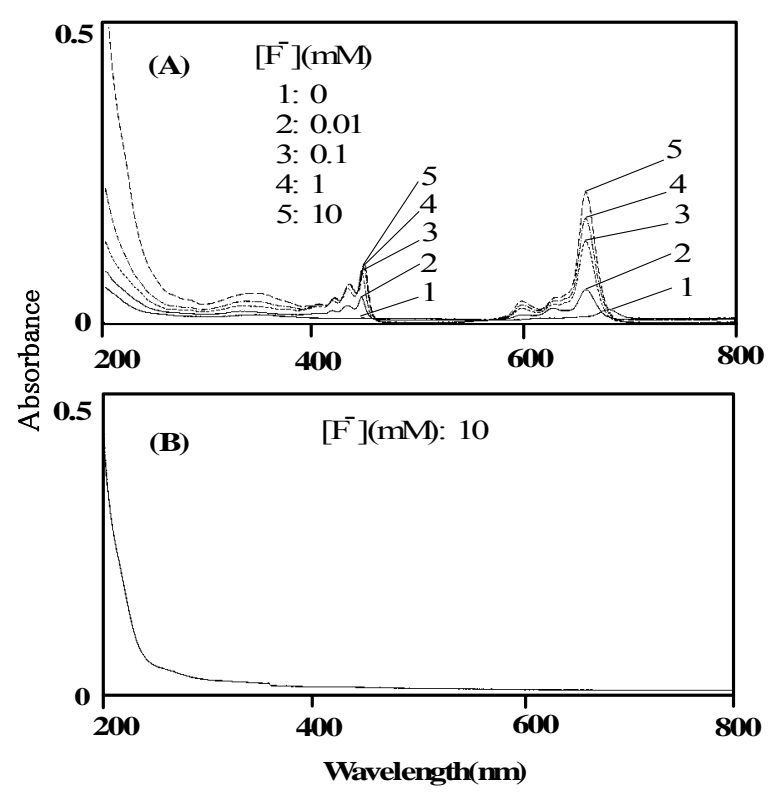

Fig. 2. UV-vis spectra of (A) (phthalocyaninato) $\mathrm{Ga}(\mathrm{III})\left([\mathrm{Ga}(\mathrm{pc})]^{+}\right)$saturated acetonitrile containing various concentration of $\mathrm{F}^{-}$(the concentration of $[\mathrm{Ga}(\mathrm{pc})]^{+}$is lower than 0.01

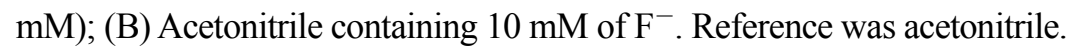

The original $[\mathrm{Ga}(\mathrm{pc})] \mathrm{Cl}$ saturated $\mathrm{AN}$ solution had a small absorption peak at $678 \mathrm{~nm}$. However, the peak almost disappeared and new peaks at about $660 \mathrm{~nm}$ and 410-450 nm appeared and became higher according to 
the addition of $\mathrm{F}^{-}$. The adding compound itself did not exhibit any absorbance in AN. Almost the same behaviors were observed in the case of the adding of $\mathrm{CN}^{-}$. The phenomena were different from the UV-vis spectra of $\mathrm{Co}(\mathrm{pc})$ with $\mathrm{F}^{-}$and $\mathrm{CN}^{-}$in $\mathrm{AN}$ [8]. The original $\mathrm{Co}(\mathrm{pc})$ saturated $\mathrm{AN}$ solution showed no sharp absorption peak at the UV-vis spectra, however, after the addition of $\mathrm{F}^{-}$, a new adsorption peak appeared at longer wavelength but no new peak could be found at shorter wavelength region.

On the other hand, as shown in Fig.3, when $\mathrm{Br}^{-}$was added to $[\mathrm{Ga}(\mathrm{pc})] \mathrm{Cl}$ saturated AN solution the original absorption peak at $678 \mathrm{~nm}$ did not show any change even if the concentration of $\mathrm{Br}^{-}$became higher. Furthermore, no new peak could be found at $410-450 \mathrm{~nm}$ although such peaks appeared in the case of $\mathrm{CN}^{-}$and $\mathrm{F}^{-}$. Almost the same behaviors were observed both in the case of $\mathrm{Br}^{-}$and $\mathrm{Cl}^{-}$. The results mean that $[\mathrm{Ga}(\mathrm{pc})]^{+}$ interact strongly with $\mathrm{F}^{-}$and $\mathrm{CN}^{-}$but only weakly with $\mathrm{Cl}^{-}$and $\mathrm{Br}^{-}$.

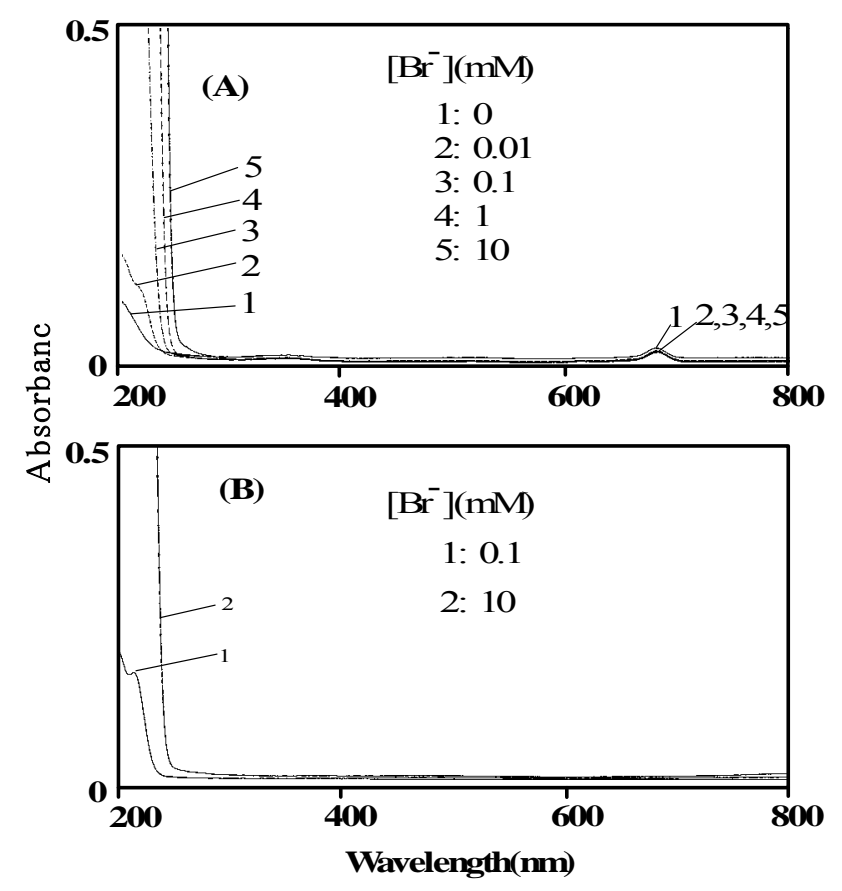

Fig. 3. UV-vis spectra of (A) (phthalocyaninato) $\mathrm{Ga}(\mathrm{III})\left([\mathrm{Ga}(\mathrm{IIII})(\mathrm{pc})]^{+}\right)$saturated acetonitrile containing various concentration of $\mathrm{Br}^{-}$(the concentration of $[\mathrm{Ga}(\mathrm{pc})]^{+}$is lower than $0.01 \mathrm{mM}$ );

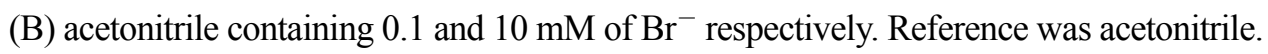


According to J. Wynne Kenneth's work [12], crystal and molecular structure of $\mathrm{Ga}(\mathrm{pc}) \mathrm{Cl}$ is that square-pyramidal coordination exists about $\mathrm{Ga}$ with $\mathrm{Cl}$ occupying the apex. The bond distances are as follows: Ga-Cl 2.217, Ga-N(1) 1.79, Ga-N(2) 1.981, Ga-N(3) 1.983, Ga-N(4) 1.9988 $\AA$. On the other hand, the crystal and molecular structure of $[\mathrm{Ga}(\mathrm{pc}) \mathrm{F}]_{\mathrm{n}}$ is that $\mathrm{Ga}$ is octahedrally coordinated by $2 \mathrm{~F}$ atoms and $4 \mathrm{~N}$ atoms of a

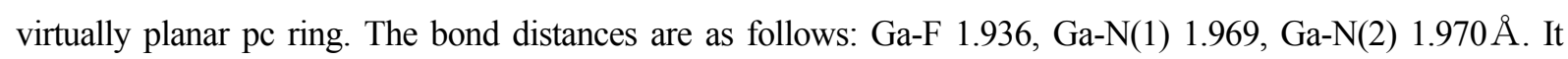
should be noted that the bond distance of $\mathrm{Ga}-\mathrm{Cl}$ is much larger than $\mathrm{Ga}-\mathrm{F}$ and $\mathrm{Ga}-\mathrm{N}$. The bond energy should be in the order of $\mathrm{E}_{\mathrm{Ga}-\mathrm{N}} \gg \mathrm{E}_{\mathrm{Ga}-\mathrm{Cl}}$. From the UV-vis results shown above and the bond distance data, it can be deduced that when $[\mathrm{Ga}(\mathrm{pc})] \mathrm{Cl}$ was dissolved in $\mathrm{AN}$, it might be dissociated by the solvation of $\mathrm{AN}$ to form $[\mathrm{Ga}(\mathrm{pc})]^{+}$, which showed an absorption peak at $678 \mathrm{~nm}$ on $\mathrm{UV}$-vis spectra. When $\mathrm{F}^{-}$was added to the solution, it should be considerable that a complexing reaction between $[\mathrm{Ga}(\mathrm{pc})]^{+}$and $\mathrm{F}^{-}$would occur to form $[\mathrm{Ga}(\mathrm{pc}) \mathrm{F}]$ due to the larger bonding energy of Ga-F. According to the molecular orbital theory of coordination chemistry, the molecular orbital energy will be changed when the electron density of ligand become higher. It is apparent that the change would cause a change of the UV-vis spectra of the complexes. We can observe that the spectra of [Ga(pc)F] (2-5 in Fig.2 A) has an absorption peak at about $660 \mathrm{~nm}$ and three peaks at 410-450 nm, which is different from that of $[\mathrm{Ga}(\mathrm{pc})]^{+}$(1 in Fig.2 A). The three peaks at 410-450 nm should be all due to the complex of $[\mathrm{Ga}(\mathrm{pc}) \mathrm{F}]$ because $[\mathrm{Ga}(\mathrm{pc})] \mathrm{Cl}$ or $\mathrm{F}^{-}$itself in $\mathrm{AN}$ does not show any absorption in this region as can be seen in 1 of Fig.2 A and Fig.2 B. The complex formation reaction of $\mathrm{F}^{-}$with $[\mathrm{Ga}(\mathrm{pc})]^{+}$may occur also because the acidity[13] of AN, whose acceptor number[14] is 18.9, is very weak, so $\mathrm{F}^{-}$in $\mathrm{AN}$ is in a extraordinarily active. On the other hand, according to the theory of coordination chemistry the complexing ability of the ions is in the order of $\mathrm{CN}^{-} \gg \mathrm{F}^{-} \gg \mathrm{Cl}^{-}>\mathrm{Br}^{-}, \mathrm{CN}^{-}$would complex with $[\mathrm{Ga}(\mathrm{pc})]^{+}$due to the high complexing ability of it. As a result, the equilibria both between $\mathrm{F}^{-}$and $[\mathrm{Ga}(\mathrm{pc}) \mathrm{F}]$ and $\mathrm{CN}^{-}$and $[\mathrm{Ga}(\mathrm{pc})(\mathrm{CN})]$ at the sensor membrane-solution interface were established. 
In $[\mathrm{Ga}(\mathrm{pc})] \mathrm{Cl}$ saturated $\mathrm{AN}$ solution, $\mathrm{Cl}^{-}$should be solvated with $\mathrm{AN}$ and exists as the counter ion of $[\mathrm{Ga}(\mathrm{pc})]^{+}$expecting by the fact that the relative permittivity of AN ( 35.9) [15] is not very low and the complexing ability of $\mathrm{Cl}^{-}$is very weak, although $\mathrm{Cl}^{-}$atom may be bonded with $\mathrm{Ga}$ in the crystal of $[\mathrm{Ga}(\mathrm{pc})] \mathrm{Cl}$ crystal, suggests that in $[\mathrm{Ga}(\mathrm{pc})] \mathrm{Cl}$ saturated $\mathrm{AN}$ solution, $\mathrm{Cl}^{-}$becomes solvated with $\mathrm{AN}$ and just acts as the counter ion to $[\mathrm{Ga}(\mathrm{pc})]^{+}$. When $\mathrm{Br}^{-}$is added to the solution, it may also exist as a AN solvated ion for the same reason. Possibly, no coordination reaction occurs between $[\mathrm{Ga}(\mathrm{pc})]^{+}$and $\mathrm{Br}^{-}$.

\subsubsection{Spectra in DMA and NMP}

We found here that the spectra of $[\mathrm{Ga}(\mathrm{pc})] \mathrm{Cl}$ in DMA are quite different from that in $\mathrm{AN}$. As can be seen in Fig.4, a quite strong absorption peak at $676 \mathrm{~nm}$ was originally appeared on the spectra of [ $\mathrm{Ga}(\mathrm{pc})] \mathrm{Cl}$ saturated

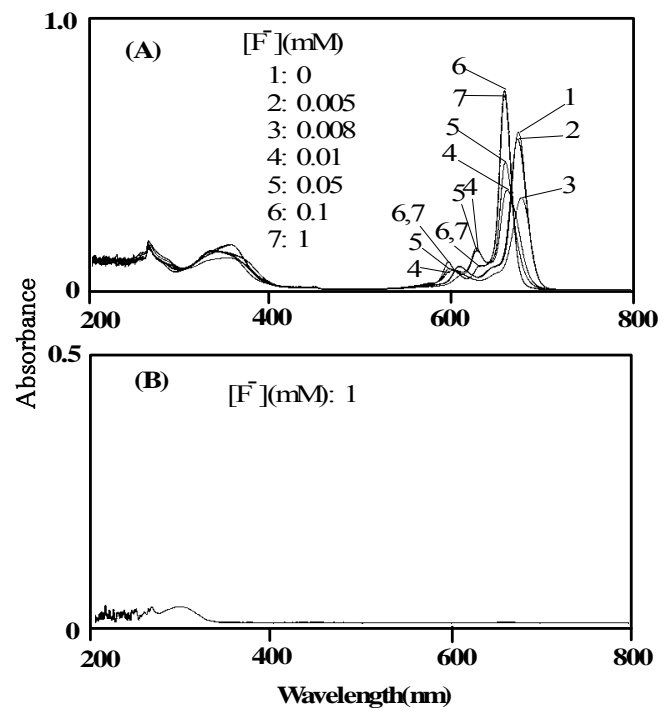

Fig. 4. UV-vis spectra of (A) (phthalocyaninato) $\mathrm{Ga}(\mathrm{III}) \quad\left([\mathrm{Ga}(\mathrm{pc})]^{+}\right)$saturated $\mathrm{N}, \mathrm{N}$-dimethylacetamide (the concentration of $[\mathrm{Ga}(\mathrm{pc})]^{+}$is lower than $0.01 \mathrm{mM}$ ) diluted by a factor of five containing various concentration of $\mathrm{F}^{-}$; (B) N,N-dimethylacetamide

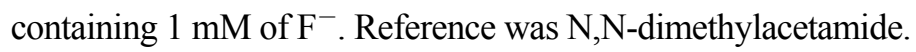

DMA solution, while just a small peak could be observed on the original UV-vis spectra of $[\mathrm{Ga}(\mathrm{pc})] \mathrm{Cl}$ saturated 
AN solution. It may be due to the more solubility of $[\mathrm{Ga}(\mathrm{pc})] \mathrm{Cl}$ in DMA than in AN. The peak at $676 \mathrm{~nm}$ should be due to $[\mathrm{Ga}(\mathrm{pc})]^{+}$from the same reason as mentioned for the case in $\mathrm{AN}$,. Here, the peak shifts a few nanometer to short wavelengths than in AN. It might be caused by the solvation strength difference between DMA and AN. According to the addition of $\mathrm{F}^{-}$, the peak decreased and a new peak at about $660 \mathrm{~nm}$ increased gradually. A complex formation reaction of $[\mathrm{Ga}(\mathrm{pc})]^{+}$with $\mathrm{F}^{-}$in DMA would predominantly occur and the newly appeared peak at about $660 \mathrm{~nm}$ should be attributed to the production of $\left[\mathrm{Ga}(\mathrm{pc}) \mathrm{F}_{2}\right]^{-}$. In the case of $\mathrm{CN}^{-}$, the same behavior as that of $\mathrm{F}^{-}$in DMA was observed. As a result, like in $\mathrm{AN}$, the complexing equilibria both between $\mathrm{F}^{-}$and $[\mathrm{Ga}(\mathrm{pc}) \mathrm{F}]$ and $\mathrm{CN}^{-}$and $[\mathrm{Ga}(\mathrm{pc}) \mathrm{CN}]$ at the sensor membrane-solution interface were established, respectively. Thus, the electrode potential could be established and the electrode could also show thermodynamic response to $\mathrm{CN}^{-}$and $\mathrm{F}^{-}$in DMA.

When $\mathrm{Br}^{-}$was added to the $[\mathrm{Ga}(\mathrm{pc})] \mathrm{Cl}$ saturated DMA solution, the UV-vis spectra of the solution just showed a very little change as shown in Fig.5. Almost the same behavior could observed in the case of $\mathrm{Cl}^{-}$as that of $\mathrm{Br}^{-}$in DMA. These also mean that the complex formation reaction of $\mathrm{Br}^{-}$and $\mathrm{Cl}^{-}$with $[\mathrm{Ga}(\mathrm{pc})]^{+}$did not proceed appreciably. The behaviors of UV-vis spectra concerning all of the above ions in NMP were similar to those in DMA.

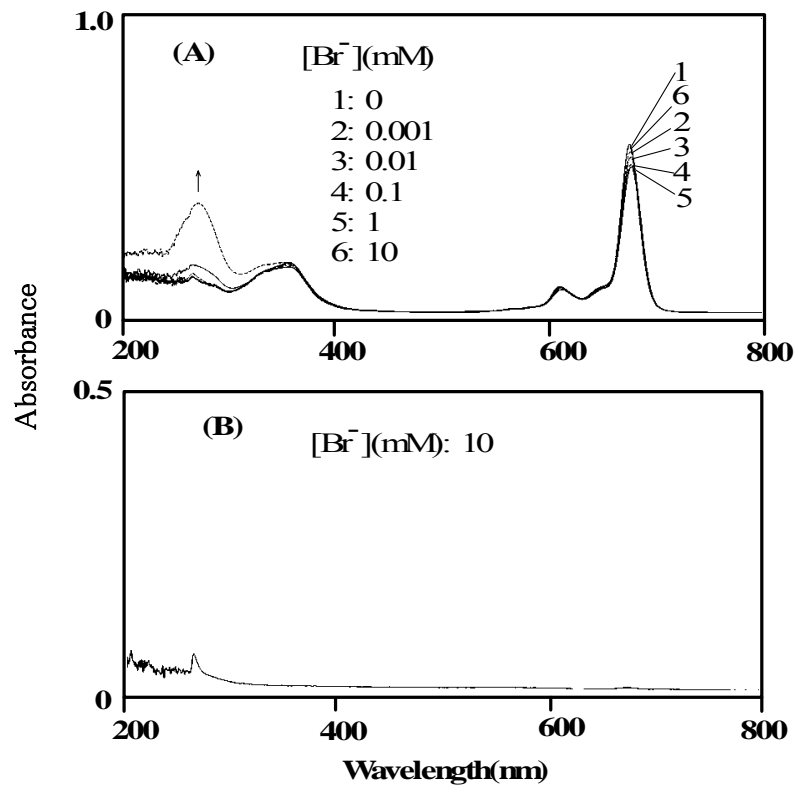


Fig. 5. UV-vis spectra of (A) (phthalocyaninato) $\mathrm{Ga}(\mathrm{III})\left([\mathrm{Ga}(\mathrm{pc})]^{+}\right)$saturated $\mathrm{N}, \mathrm{N}$-dimethylacetamide (the concentration of $[\mathrm{Ga}(\mathrm{pc})]^{+}$is lower than $0.01 \mathrm{mM}$ ) diluted by a factor of five containing various concentration of $\mathrm{Br}^{-}$; (B) N,N-dimethylacetamide

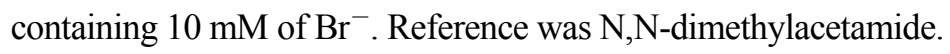

The absorption maximum of $[\mathrm{Ga}(\mathrm{pc})] \mathrm{Cl}$ saturated AN, DMA and DMF solution shifted more than $15 \mathrm{~nm}$ when $\mathrm{F}^{-}$and $\mathrm{CN}^{-}$were added while those were less than $3 \mathrm{~nm}$ at the case of $\mathrm{Cl}^{-}$and $\mathrm{Br}^{-}$. It means that $[\mathrm{Ga}(\mathrm{pc})]^{+}$interact strongly with $\mathrm{F}^{-}$and $\mathrm{CN}^{-}$but weakly with $\mathrm{Cl}^{-}$and $\mathrm{Br}^{-}$in all above solvents.

\subsection{Cyclic voltammetric results}

Cyclic voltammetric investigations for the interactions of $[\mathrm{Ga}(\mathrm{pc})]^{+}$with $\mathrm{F}^{-}$and $\mathrm{Br}^{-}$in DMA were carried out. The results were shown in Fig.6: curve (a) was the CV of blank solution, i.e., $100 \mathrm{mM} \mathrm{Et} 4 \mathrm{NClO}_{4}$ in

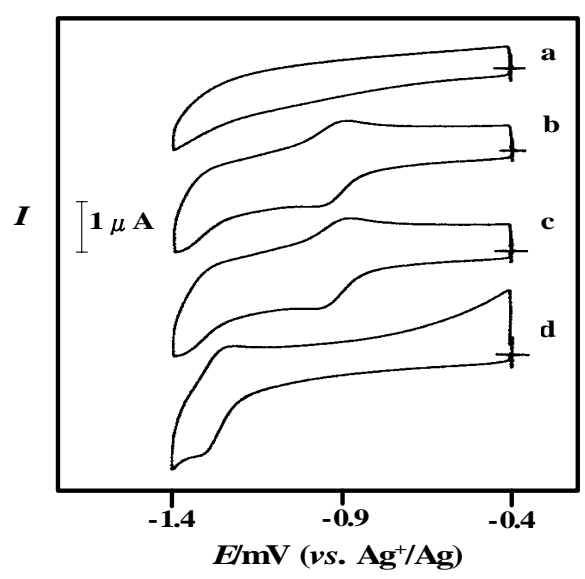

Fig. 6. Cyclic voltammograms recorded at platinum disk electrode in (a) $0.1 \mathrm{M} \mathrm{Et}_{4} \mathrm{NClO}_{4}$

DMA solutions; (b) $[\mathrm{Ga}(\mathrm{pc})] \mathrm{Cl}$ saturated $0.1 \mathrm{M} \mathrm{Et}_{4} \mathrm{NClO}_{4} \mathrm{DMA}$; (c) $[\mathrm{Ga}(\mathrm{pc})] \mathrm{Cl}$ saturated 0.1 $\mathrm{M} \mathrm{Et}_{4} \mathrm{NClO}_{4}$ DMA containing $1 \mathrm{mM} \mathrm{Et} 4 \mathrm{NBr}$; (d) $[\mathrm{Ga}(\mathrm{pc})] \mathrm{Cl}$ saturated $0.1 \mathrm{M} \mathrm{Et}_{4} \mathrm{NClO}_{4} \mathrm{DMA}$ containing $1 \mathrm{mM} \mathrm{Bu} 4 \mathrm{NF} \cdot 3 \mathrm{H}_{2} \mathrm{O}$. Scan rate was $0.100 \mathrm{~V} / \mathrm{s}$.

DMA; curve (b) was the CV of blank solution saturated with $[\mathrm{Ga}(\mathrm{pc})] \mathrm{Cl}$; curve (c) was the $\mathrm{CV}$ of blank solution 
saturated with $[\mathrm{Ga}(\mathrm{pc})] \mathrm{Cl}$ containing $1 \mathrm{mM} \mathrm{Et}_{4} \mathrm{NBr}$; curve (d) was the $\mathrm{CV}$ of blank solution saturated with $[\mathrm{Ga}(\mathrm{pc})] \mathrm{Cl}$ containing $1 \mathrm{mM} \mathrm{Et} \mathrm{t}_{4} \mathrm{NF} \cdot 3 \mathrm{H}_{2} \mathrm{O}$. In this figure, the peak-to-peak separations indicate reversible electron transfer was taking place [16]. The half-wave potentials of this redox couple for [Ga(pc) $]^{+}$in DMA was $-920 \mathrm{mV}$ (vs. $\mathrm{Ag}^{+} / \mathrm{Ag}$, which potential is $75 \mathrm{mV}$ less than $\mathrm{Fc}^{+} / \mathrm{Fc}$ ). The redox peaks and half-wave potential had no change when $\mathrm{Br}^{-}$was added. However, it changed to $-1.27 \mathrm{~V}$ as the adding of $\mathrm{F}^{-}$. It means that $\mathrm{F}^{-}$ coordinated strongly with the oxidized form than the reduced form.

The potentiometric, cyclic voltammetric, and spectrophotometric experimental results reveal that PAA-[Ga(pc)] electrode, similar to the PAA-[Co(pc)] and $[\mathrm{Sn}(\mathrm{pc})]$ electrode, showed Nernstian or near-Nernstian responses to $\mathrm{F}^{-}$and $\mathrm{CN}^{-}$obviously due to the reaction of the host compound in the sensor membrane with the ions, but showed a non-Nernstian response to the ions, $\mathrm{Cl}^{-}$and $\mathrm{Br}^{-}$, that display a weak interaction with the host compound in all of the above solvents. There are not remarkable difference among the responses of PAA-[Ga(pc)], PAA-[Co(pc)], and PAA-[Sn(pc)] electrode to $\mathrm{CN}^{-}, \mathrm{F}^{-}, \mathrm{Cl}^{-}$, and $\mathrm{Br}^{-}$. The potentiometric response of the electrode is based on the coordination of the analyte ion as an axial ligand to the center metal of the host compound, $[\mathrm{Ga}(\mathrm{pc})]$. This phase-boundary potential model was well discussed by $\mathrm{E}$. Bakker et al [17].

3.4 Determination of the selectivity coefficient

The selectivity coefficient of PAA-[Ga(pc)] electrode for $\mathrm{F}^{-}$over $\mathrm{CN}^{-}, \mathrm{K}_{\mathrm{F}^{-}, \mathrm{CN}^{-}}$, and $\mathrm{CN}^{-}$over $\mathrm{F}^{-}, \mathrm{K}_{\mathrm{CN}^{-}, \mathrm{F}^{-}}$, in $\mathrm{AN}$ were measured by mixed solution method described by P. Buhlmann et al [18]. $\mathrm{K}_{\mathrm{F}^{-}, \mathrm{CN}^{-}}$was obtained by preparing $\mathrm{F}^{-}$calibration curve in the presence of a fixed concentration of $\mathrm{CN}^{-}\left(10^{-4} \mathrm{M}\right)$ while $\mathrm{K}_{\mathrm{CN}^{-}}$, $\mathrm{F}^{-}$was obtained by preparing $\mathrm{CN}^{-}$calibration curve in the presence of a fixed concentration of $\mathrm{F}^{-}\left(10^{-4} \mathrm{M}\right)$. The results showed that both $\mathrm{K}_{\mathrm{F}^{-}, \mathrm{CN}^{-}}$and $\mathrm{K}_{\mathrm{CN}^{-}, \mathrm{F}^{-}}$nearly equal to 1 . This indicates that both $\mathrm{F}^{-}$and $\mathrm{CN}^{-}$have almost the 
same ability to bind with the centre metal of $[\mathrm{Ga}(\mathrm{pc})]^{+}$at the axial position and the Standard Gibbs Energy of the reactions both between $[\mathrm{Ga}(\mathrm{pc})]^{+}$and $\mathrm{F}^{-}$and $[\mathrm{Ga}(\mathrm{pc})]^{+}$and $\mathrm{CN}^{-}$may be similar. This result can also be deduced from the UV spectra about the interaction of $[\mathrm{Ga}(\mathrm{pc})]^{+}$with $\mathrm{F}^{-}$and $\mathrm{CN}^{-}$in acetonitrile, i.e., when $\mathrm{F}^{-}$ and $\mathrm{CN}^{-}$were added respectively to $[\mathrm{Ga}(\mathrm{pc})]^{+}$saturated $\mathrm{AN}$ solution, the peak at about $678 \mathrm{~nm}$ shifted similarly to the short wavelength.

3.5 Determination of the solubility product constant of sodium fluoride in $\mathrm{AN}\left(\mathrm{K}_{\mathrm{sp}}^{\mathrm{AN}} \mathrm{NaF}\right)$.

The single ion standard molar Gibbs free energy of transfer [19] is an important thermodynamic data to discuss the effects of solvent properties on chemical reactions. The solubility product of electrolyte is related to the single ion standard molar Gibbs free energy of transfer.

In order to confirm the thermodynamic applicability of the PAA- $[\mathrm{Ga}(\mathrm{pc})]$ electrode, an experiment was carried out for obtaining the solubility product of $\mathrm{NaF}$ in $\mathrm{AN}\left(\mathrm{K}_{\mathrm{sp} \text { (NaF) }}^{\mathrm{AN}}\right)$. A $10 \mathrm{ml}$ of $2 \mathrm{mM} \mathrm{Bu} \mathrm{Nu}_{4} \mathrm{NF}_{3} 3 \mathrm{H}_{2} \mathrm{O}$ in $10 \mathrm{mM} \mathrm{Bu}_{4} \mathrm{NClO}_{4}-\mathrm{AN}$ solution was titrated with a $50 \mathrm{mM} \mathrm{NaClO}_{4}-\mathrm{AN}$ solution at $25^{\circ} \mathrm{C}$. The titration curve and dynamic response curve are shown in Fig.7. The $\mathrm{pK}_{\mathrm{sp}}^{\mathrm{AN}}$ (NaF) obtained was 10 and it should be noted that the solubility product constant contains $\mathrm{NaF}$ dissolved in AN. The result agreed well with that obtained previously by the PAA-[Co(pc)] and the PAA-[VO(pc)] electrode[8, 9], suggesting the electrode developed in the work also should be able to use for the thermodynamic study in nonaqueous solutions.

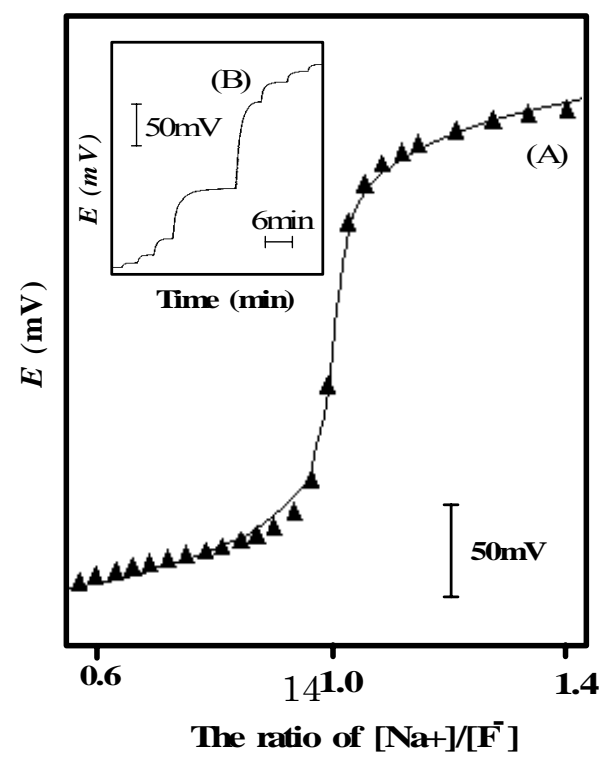


Fig. 7. (A) Titration curve of a $10 \mathrm{ml}$ of $2 \mathrm{mM} \mathrm{Bu} 4 \mathrm{NF} \cdot 3 \mathrm{H}_{2} \mathrm{O}$ with $50 \mathrm{mM} \mathrm{NaClO}{ }_{4}$ in $\mathrm{AN}$ by PAA-[Ga(pc)] electrode. $(\mathbf{\Lambda})$ and $(-)$ show the measured and calculated values, respectively. (B) Dynamic response curve near the end point of the titration of $\mathrm{Bu}_{4} \mathrm{NF}$ with $\mathrm{NaClO}_{4}$ in $\mathrm{AN}$ at PAA-[Ga(pc)] electrode. One step on the curve corresponds to one drop of the titrant.

\section{Conclusions}

The PAA-[Ga(pc)] electrode showed selective Nernstian or near-Nernstian responses to $\mathrm{F}^{-}$ and $\mathrm{CN}^{-}$in AN, DMA, and NMP. The establishment of the membrane potential was successfully confirmed by UV-vis spectrophotometric and cyclic voltammetric measurement. The potentiometric response of the electrode was based on the coordination of the analyte ion as an axial ligand to the center metal of the host compound. $\mathrm{F}^{-}$and $\mathrm{CN}^{-}$have almost the same ability to bind with the center metal of $[\mathrm{Ga}(\mathrm{pc})]^{+}$at the axial position in all of solvents used in this study. The electrode developed here can be used to determine the solubility product of $\mathrm{NaF}$ in $\mathrm{AN}$. 


\section{References}

[1] E. D. Steinle, U. Schaller, and M. E. Meyerhoff, Anal. Sci. 14 (1998) 79.

[2] M. K. Amini, S. Shahrokhian, S. Tanfestaninejad, Anal. Chim. Acta. 402 (1999) 137.

[3] M. K. Amini, S. Shahrokhian, S. Tanfestaninejad, Anal. Lett. 32 (1999), 2737.

[4] N. Nensala, T. Nyokong, Polyhedron. 15 (1996) 867; T. Nyokong, Z. Gasyna, M.J. Stillman, Inorg. Chem. 26 (1987) 548; M.D. Maree, T. Nyokong, J. Porph. Phthalo. 5 (2001) 555.

[5] M. Kimura, Y. Yamaguchi, T. Muto, K. Hanabusa, H. Shirai, J. Porphyrins Phthalocyanines. 4 (2000) 123.

[6] S-J. Kim, M. Matsumoto, K. Shigehara, J.Porphyrins Phthalocyanines. 4 (2000) 136.

[7] N. Kobayashi, H. Miwa, V. N. Nemykin, J. Am. Chem. Soc. 124 (2002) 8007.

[8] T. Nakamura, C. Hayashi, T. Ogawara, Bull. Chem. Soc. Jpn. 69 (1996) 1555.

[9] T. Nakamura, T. Ueda, T. Yanagisawa, H. Watanabe, Bull. Chem. Soc. Jpn. 72 (1999) 235.

[10] T. Nakamura, J. Ren, T. Hinoue, K. Umemoto, Anal. Sci. 19 (2003) 991.

[11] K. Izutsu, T. Nakamura, M. Muramatsu, Y. Aoki, J. Electroanal. Chem. 297 (1991) 49.

[12] J. Wynne Kenneth, Inorg. Chem., 23 (1984) 4658; 24 (1985) 1339.

[13] Gary D. Christian, Analytical Chemistry(sixth edition), John wiley \&Sons, Inc., USA, 2004, p.221.

[14] V. Gutmann, The Donor-Acceptor Approach to Molecular Interactions, Plenum Press, New York, 1978, p.27.

[15] K. Izutsu, Electrochemistry in Nonaqueous Solutions, 2002, WILEY-VCH, Weinheim, p.6.

[16] A. J. Bard, L. R. Faulkner, Electrochemical Methods, Fundamentals and Applications (second edition), Wiley, New York, 2001.

[17] E. Bakker, P. Bühlmann, E. Pretsch, Talanta, 62 (2004) 843.

[18] E. Bakker, E. Pretsch, P. Buhlmann, Anal. Chem., 72 (2000) 1127.

[19] Y. Marcus, Ion Salvation, John Wiley \& Sons, New York, 1975, p.152. 